\title{
Flexible Learning Itineraries Based on Conceptual Maps
}

\author{
Olga Lucía Agudelo', Jesús Salinas²* \\ ${ }^{1}$ Secretariat of Education, Medellin, Colombia \{olga.agudelo@futurodigital.org\} \\ ${ }^{2}$ Departament of Applied Pedagogy and Psychology, University of the Balearic Islands, Spain \\ \{jesus.salinas@uib.es\} \\ Received on 20 March 2015; revised on 29 March 2015; accepted on 11 April 2015; published on 15 July 2015. \\ DOI: 10.7821/naer.2015.7.130
}

\begin{abstract}
The use of learning itineraries based on conceptual maps is studied in order to propose a more flexible instructional design that strengthens the learning process focused on the student, generating non-linear processes, characterising its elements, setting up relationships between them and shaping a general model with specifications for each educational level. Through a methodology built on the Successive Approximation Model (SAM), this article studies learning itinerary design, implementation and assessment process, representing, through non-linear organised conceptual maps, sets of activities leading to the development of competencies that must be understood, mastered and demonstrated. Obtained results show the adequacy of a learning itinerary based on conceptual maps of the subjects' characteristics, solving real situations through the construction and creation of new schemes and knowledge management methods while contributing to a reflection on curricular design principles using ICT and generating learning-process autonomy.
\end{abstract}

KEYWORDS: LEARNING ENVIRONMENTS, INSTRUCTIONAL DESIGN, CONCEPTUAL MAPS, ICT

\section{INTRODUCTION}

Great advances have been made in the teaching of planning focused on competencies and the incorporation of teachers' experience in information and communication technologies (ICT) in training processes, which are improving as well.

Nevertheless, there are countless cases where practices for competency development and ICT integration into pedagogical processes are in fact reproducing a traditional focus. This latter strategy has little to do with the development of the competencies required by the citizens of the twenty-first Century who need to get on in an advanced technological and global world. These practices poorly reflect the innovative processes required by today's education.

The number of teachers interested in new tools, strategies and technologies to support their work has been growing, although sometimes they do not find an effective way to pursue these. And teachers, being precisely the educational system actors, are

\footnotetext{
*To whom correspondence should be addressed:

Secretaría de Educación de Medellín

Calle 7 N48-111 Av Las Vegas, Medellín, Colombia
}

the first ones called to propose and execute actions aimed at enabling their students to develop expected competencies, supported by the theories, pedagogical perspectives and new tools made available by ICT in order to facilitate teaching and learning processes.

Pedagogical research, innovation and reflection have to face these challenges and propose new instructional designs that are student-centred and more flexible, responding, furthermore to the need for learners to take control of the learning process more autonomously.

Consequently, we have implemented a project based on the proposal of Novak and Cañas (2010), using conceptual maps to design flexible learning itineraries and seeking the development of basic, specific or digital competencies, as well as a more active and autonomous student participation in the proposed activities and in the design of their learning process. The project is initially developed in the context of basic high school education, It will be applied at a later stage to other educational levels and contexts and by different educational agents.

\section{REFERENCE FRAMEWORK}

The project is based on learning environments supported by ICT, on instructional design and, finally, on conceptual maps and their support of training itinerary design, where self-planned learning stands out as a confluence point and as a required element within a flexible training process.

From this analysis, we determine the characteristics of instructional design in an ICT-supported learning environment, with specific flexible learning itineraries based on conceptual maps.

\section{$2.1 \quad$ ICT-Supported Learning Environments}

The appearance of new ICT-based learning environments requires a redefinition of the traditional models in order to advance towards a more flexible learning-teaching type of process (Salinas, 2004). Although traditional learning environments have not been replaced, they are now complemented, diversified and enriched with new proposals that allow information adaptation to a social environment.

A learning environment is understood as a "space" where knowledge acquisition and construction process takes place, and includes the organisation of the space, of the teaching resources, the management of time, the strategies used and the instructions that take place in the classroom.

In this context, new educational environments make reference to the impact ICT has on traditional scenarios and to the design 
of new learning spaces. There is a full range of learning resources, educational communications, space organisation and accessibility possibilities that must be taken into account, particularly for futuristic projections. From a pedagogical perspective, approaches related to flexible education may lead to a new concept, which, independently from teaching being inclass, blended or distance learning, provides the student with a variety of means and the possibility to make learning decisions (Salinas, 1999; Tait, 1999). Although the influence of technology is evident in every component of the learning environment, it is more openly reflected in the organisation of space, time and resources.

\subsection{Instructional Design}

How can instructors best structure and sequence the contents of a discipline to make knowledge or learning experiences available to those subjects willing to learn? This is the problem good instructional design must solve.

According to Berger and Kam (1996) from Penn State University Applied Research Laboratory, instructional design is the systematic process that leads to the creation of instructional systems, while instructional development is the process of implementing this system or plan and includes its assessment and maintenance. Both processes must combine and support each other's teaching and learning theories, as well as reflect research on educational practice in the classroom.

A review of definitions reveals that, for some authors, creating an instructional environment with clear and effective materials to help students develop the capacity to comply with their tasks is an applied art and science (Broderick, 2001). Also, Berger and Kam (1996) define it as the creation of a thorough specification for the development, implementation, assessment and maintenance of situations that facilitate learning small and large content units.

Coll (2005) outlines the potentiality of educational design ICT, taking the constructivist approach of teaching and learning processes as a frame of reference. These characteristics, from the design perspective of a learning environment, have an impact on the relationship among educational agents, resources and contents through the generation of new assessment means.

The arrangement of new learning environments and a flexible design using new representational forms is another characteristic of ICT-enriched instructional developments. When highlighting the components that shape an ICT-supported training environment, we find a variety of proposals (Collis \& Moneen, 2001; Salinas, 2004). Considering these components helps in sorting out the elements that must be taken into account for flexible training environments and for the new learning scenarios, as well as their design, management and related research.

Among the new ways of guiding educational actions provided by ICT, are the following (Ospina, 2008):

The possibility of access to information and communication (digital and hypertext material).

The freedom of students to guide their actions, while widening their conception of what, where and with whom it is possible (and required) to learn.

The widening of learning strategies.

The relationship with technologies and the possibilities to learn with and from technology.
The evidence that cognitive effects, thanks to the interaction with information technology, strategic thought modifications, representational forms, metacognition strategies, various ways of seeing the world and certain information processing and communication skills, effectively serve as guidelines supporting and organising the learning process.

A reframing of the teaching-learning classroom concept.

A renewed way to understand student interaction, because the use of ICT exponentially increases communication possibilities - and limitations - that may be achieved with these technologies but not with others.

The possibility to improve some cognitive skills that directly depend on the specific stimulus of each tool, widening the repertoire of our thoughts and cooperation.

The use of technology in education presents a change of linear to interactive learning. Lozano and Burgos (2007) recognise that in the traditional model, knowledge is teacher-centred with a linear one-way scheme: teacher to student with the latter having little participation; new learning models entails a transition to knowledge construction based on "discovery and participation”.

\subsection{Conceptual Maps}

Cognitive connections refer to the link generated between previous knowledge and new knowledge. Ausubel's assimilation theory is based on a constructivist model, and centers on the interaction process between recently learned material and existing concepts (Ausubel, Novak \& Hanesian, 1983). The richer a learner's cognitive structure, the more interconnections he/she will be able to achieve between new information and that already possessed. These interconnections make learning significant, because it is incorporated with knowledge the individual already has and may be used later in other fields according to his/her needs or interests.

Conceptual maps are the main methodological tool of assimilation theory for determining what the student already knows (Cañas et al., 2000; Cañas, Novak, Reiska, 2015). They are the graphic representation of a set of concepts and the significant relationships between them under the proposal or a simplified-phrase form: two or more concepts linked by words to form a semantic unit. Concepts are organised in such a way that they generate hierarchical structures.

As a starting point, conceptual maps use focus questions to provide a global sense. Surfing a map allows greater user control because, since it is not linear, it offers reading alternatives according to the reader's level of understanding.

This way of representing knowledge may be softwareenriched to facilitate the creation of the learner's own maps and to facilitate the range of possibilities, and can include CmapTools, which are developed by the Institute for Human and Machine Cognition (IHMC), to enrich conceptual maps with resources (files) attached to the concepts or link phrases, as well as offer possibilities to register the construction process. CmapTools also include synchronic or non-synchronic collaborative work tools, presentation tools, alternatives to export the generated file and free servers to store, search and share maps and map comparison modules, as well as formatting tools.

Conceptual maps are used in classrooms to help students represent their cognitive structures and self-built knowledge, to identify research processes, to show question results that have 
guided the development of an educational process, to interpret theories, readings and literary works, to design proposals and to organise collaborative work (Novak \& Cañas, 2006). Every one of them may be incorporated one way or another into didactic strategies in teaching and learning processes.

Another conceptual map application is set up by the learning itineraries proposed by Cañas and Novak (2010). Instead of explaining the issue through proposals, as happens with maps enriched with resources and links to other maps, like knowledge models, they are aimed at how to learn the subject. Therefore, they deal with the 'how' instead of with the 'what'. Learning itineraries based on conceptual maps "are, therefore, a way to organise a learning process and present a series of routes, options and resources to develop a competency or knowledge supported on learning objects that guide the learning subject” (Agudelo \& Salinas, 2013).

\subsection{Learning Itineraries}

Novak and Gowin (1984) consider the teacher to be a mediator between the conceptual structure of the disciplines and the cognitive structure of the student. The result of this mediation is the change of the cognitive structure that generates the learning and the mediation that takes place through the instructional design set out to achieve it. Learning itineraries based on conceptual maps facilitate comprehensive and hierarchical browsing through learning objects and contents at a number of levels, so they are a model for curricular design (Kinchin, 2000).

Cañas and Novak (2010) conceptualise an itinerary as a conceptual map that serves as a guideline for students to know how to study or learn a particular issue. Conceptually, an itinerary offers alternatives for the student to choose the way to proceed through foreseen activities. An itinerary does not describe the issue or recommend how the issue may be studied; therefore, it is different from a traditional descriptive concept (Coffey \& Cañas, 2003).

Salinas, de Benito and Darder (2012), meanwhile, explain that a learning itinerary responds to the need to guide students through contents, processes and activities and at the same time provide enough flexibility to exercise a certain autonomy in the learning process. Process presentation, through conceptual maps, helps sort out information in a non-linear way, showing sequential possibilities for the students through the contents, and facilitates access to learning objects that support the acquisition of knowledge and the development of competencies.

A learning itinerary allows the teacher to have real control to organise his/her subject, because it is flexible for sorting out learning contents and objects. Only when the teacher has the flexibility to organise his/her subject, is student control likely to be exercised. Conceptual maps provide such flexibility. This type of design has the following characteristics:

- Allows organizing concepts, issues to be learned and competencies to be developed, as well as the learning objects to be used.

— To give a full vision of what must be done to understand the issue.

- To offer options or alternatives to be followed in the construction of the student's own learning sequence according to individual characteristics, needs and learning style, among others.

— To use what is known as expert’s maps.
According to De Benito, Cañas, Darder and Salinas (2010), a subject that learns through itineraries based on maps, has the following advantages:

—Enough flexibility to facilitate learning process autonomy.

- Ability to consult the material in terms of the function of needs, interests, motivation and previous knowledge.

—Ability to determine the significant relationships among contents, resource, and activities.

— Ability to unload the itinerary to facilitate customizing it: identify visited nodes, add notes, link evidence and include the student's own resources and other learning objects.

— Freedom of mobility throughout the learning environment, according to the itinerary design.

- Ability to interact and direct the route through contents within predefined relationships.

\section{RESEARCH DESCRIPTION}

The institutional context in which the research takes place is located in the central-eastern zone of Medellin, Colombia, at the Gabriel García Máquez Educational Institution, offering educational preschool through $11^{\text {th }}$ grade services; it has 1,920 students and 54 teachers.

As Agudelo and Salinas (2013) describe, the curricular structure of the academic programs at this institution is made up of an Integrated Pedagogical Model based on several models with an emphasis on individual development, social requirements, technological processes, knowledge development and individual and social life projects with a focus on research, participation, and other aspects that are societal, technological, interdisciplinary inter-institutional, intercultural and global aspects. The ICT Management Plan has permeated academic, social, administrative and togetherness aspects and supports teachers' training to implement new technologies in the academic development of their areas, which favourably affects students' education.

\subsection{Objectives}

The project is aimed at:

— modeling flexible curricular design learning environments supported by conceptual maps in different contexts and educational levels; and

—designing and complementing learning experiences supported by flexible itineraries based on conceptual maps and characterizing intervening elements to optimize results.

\subsection{Research Methodology}

The methodology for developing this project is qualitative research based in a natural context and interpreting phenomena from the feelings of participants. Within this framework, designbased research has been followed, in which stakeholders participate together to improve a problematic situation by selecting and applying processes and generating a reflection on the practices performed (McKenney \& Reeves, 2012).

Information-Based Design (IBD) supports the exploration and design of every type of educational innovation, at didactic and organisational levels, taking into account experiences related to 
the implementation of new ICT proposals (Reeves, 2006). For this design process, SAM, a design-development-assessment successive circle formula, an agile variation of the ADDIE model design methodology, was used.

Specifically, a dual cycle was developed: a first cycle of itinerary prototype design-development-assessment, through which an assessment has been developed by experts, and a second redesign, implementation and assessment cycle has been performed by users.

\subsection{Design and Development}

The design of the itinerary started with the exploration of the curricular design, focusing on competencies, which is aimed at developing eighteen basic student competencies and seven specific ones, the latter aimed at software development. It organizes these competencies within the mandatory areas, four components were developed:

\section{— Technical Component}

\section{—Scientific Component}

\section{—Communications Component}

-Humanistic Component

As Agudelo and Salinas (2013) describe, to design the itinerary, a competency from the Technical Component was taken: information management, defined as the capacity to organize information using information tools, thereby efficiently facilitating the development of its functions. This competence has five levels and level four was retaken, corresponding to the ninth grade, to implement the experience: It interprets and generates information from analysed data.
For this design, the area of the teacher's support and expertise was available as well as the concepts retaken from the reference framework.

The areas this competence deals with belong to the Technical Component: technology, information and entrepreneurship supported by religion, part of the Humanistic Component, from which the competence is developed: construction of a life project that becomes the classroom project to provide sense to the development of this itinerary.

In order to receive suggestions for improvements, the first design was handed over to experts, competent entities and people working on issues such as instructional design, conceptual maps, training and pedagogy itinerary for validation. This was performed by four experts (instructional design, didactics, e-learning and competencies). From their observations, the itinerary was redesigned in order to obtain the itinerary to be applied (Figure 1).

This includes the application of the itinerary to the students. Parallel groups are set up with similar conditions and characteristics, that is: the same schooling level, the same age average and the same ethnographic conditions, so a control group is available to develop the competence as usual. Further, two control groups are available, one to implement the itinerary under the e-learning modality and the other to apply the blearning modality as support to the in-class work of the teacher. Groups include an average of thirty 14-to-16-year-old students.

Implementation deals with user validation and with the application of the itinerary to the students as it was being implemented and assessed by them. (Table 1)

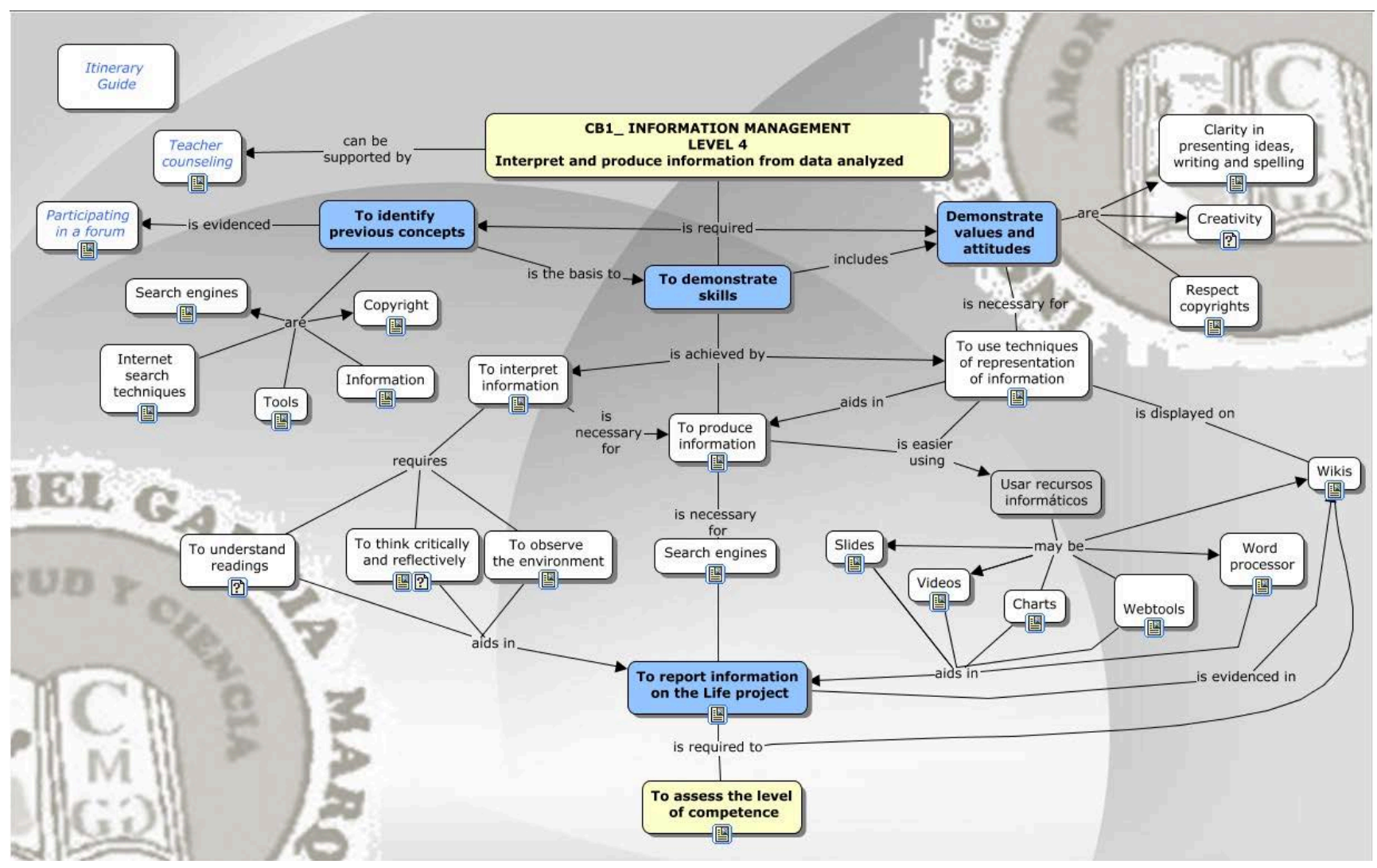

Figure 1. Applied Learning Itinerary 
Table 1. Participants

\begin{tabular}{lcc}
\hline \multicolumn{1}{c}{ Group } & Treatment & Individuals \\
\hline $9^{\circ} 1$ Grade & GE1 & 31 \\
$9^{\circ} 2$ Grade & GC & 31 \\
$9^{\circ} 3$ Grade & GE2 & 35 \\
\hline Total & & 97 \\
\hline
\end{tabular}

GE1 addressed the itinerary as an in-class process support, GC developed the competence in class without learning itinerary support and GE2 worked with the itinerary in an autonomous way with the teacher acting as a virtual tutor.

The application of learning itinerary strategies to GE1 and GE2 students $-9^{\circ} 1$ and $9^{\circ} 3$ ninth grade - facilitated the thematic compliance with the fourth period, one of the most difficult ones, given the students are ending the academic year and frequently have class absences due to the number of programmed activities, whether institutional or personal, which can have a real influence. During the implementation of the itineraries, a followup of experiences and incidences was conducted.

\subsection{Results}

Results are presented as related to three aspects:

- academic performance (based on $4^{\text {th }}$ period grades)

- level of satisfaction with the experience

- activity developed in the itinerary (used learning objects, etc.)

\subsubsection{Academic Results}

The best academic results are registered with the guided itinerary (Experimental Group 1), which gives a compliance of $61 \%$ represented with high and superior performance. Although the lowest results of these two performances took place in the itinerary without an in-class teacher (Experimental Group 2), it is important to highlight that the performance level of this group was lower than with the control group that worked under the traditional methodology, without an itinerary (Table 2).

Table 2. Academic Results

\begin{tabular}{lccc}
\hline \multicolumn{1}{c}{ Results (\%) } & $\begin{array}{c}\mathbf{9}^{\mathbf{1}} \mathbf{1} \text { Grade } \\
\text { GE1 }\end{array}$ & $\begin{array}{c}\mathbf{9}^{\mathbf{0}} \mathbf{2} \text { Grade } \\
\text { GC }\end{array}$ & $\begin{array}{c}\mathbf{9}^{\mathbf{0}} \mathbf{3} \text { Grade } \\
\text { GE3 }\end{array}$ \\
\hline Upper & $16 \%$ & $6 \%$ & $0 \%$ \\
High & $45 \%$ & $26 \%$ & $42 \%$ \\
Basic & $29 \%$ & $54 \%$ & $19 \%$ \\
Low & $3 \%$ & $0 \%$ & $16 \%$ \\
Cancelled & $7 \%$ & $14 \%$ & $23 \%$ \\
\hline Total & $100 \%$ & $100 \%$ & $100 \%$ \\
\hline
\end{tabular}

\subsubsection{Level of Satisfaction with the Experience}

Level of satisfaction with the itinerary experience was obtained through a survey conducted in the technology area of the students and teachers. Eighty-four percent of the polls were collected (Table 3).

Level of satisfaction reached $84 \%$, as reflected in a survey measuring motivation, flexibility, resources and autonomy throughout the competence development.

Those with the lowest satisfaction levels indicated they did not have the resources to access the itinerary during extracurricular time and faced difficulty in applying a new methodology.

Table 3. Level of Satisfaction

\begin{tabular}{llll}
\hline Results (\%) & $\mathbf{9}^{\mathbf{1}} \mathbf{1}$ Grade GE1 & $\mathbf{9}^{\mathbf{2}} \mathbf{2}$ Grade GC & Average \\
\hline Excellent & $30 \%$ & $19 \%$ & $25 \%$ \\
Good & $66 \%$ & $51 \%$ & $59 \%$ \\
Regular & $4 \%$ & $29 \%$ & $15 \%$ \\
Poor & $0 \%$ & $1 \%$ & $1 \%$ \\
\hline TOTAL & $100 \%$ & $100 \%$ & $100 \%$ \\
\hline
\end{tabular}

\subsubsection{Activity Developed under the Itinerary}

The learning objects visited and activities developed were observed through the participation in the proposed activities and the followup conducted according to the itinerary over the period.

On average, $80.3 \%$ of the learning objects and activities in the itinerary were performed, giving the average for the results of the two experimental groups.

Table 4. Developed Activities

\begin{tabular}{llll}
\hline $\begin{array}{l}\text { Developed activities and/or } \\
\text { learning objects visited }\end{array}$ & $\begin{array}{l}\mathbf{9}^{\mathbf{0}} \mathbf{1} \text { Grade } \\
\text { GE1 }\end{array}$ & $\begin{array}{l}\mathbf{9}^{\mathbf{2}} \mathbf{2} \\
\text { Grade } \\
\text { GC }\end{array}$ & $\begin{array}{l}\mathbf{9}^{\mathbf{0}} \text { Grade } \\
\text { GE2 }\end{array}$ \\
\hline Slideshows & $45 \%$ & $15 \%$ & $30 \%$ \\
Word processor & $45 \%$ & $15 \%$ & $35 \%$ \\
Excel charts & $25 \%$ & $5 \%$ & $20 \%$ \\
Videos & $33 \%$ & $11 \%$ & $21 \%$ \\
Wiki & $45 \%$ & $12 \%$ & $33 \%$ \\
Web tools & $46 \%$ & $11 \%$ & $35 \%$ \\
Digital book & $2 \%$ & $0 \%$ & $0 \%$ \\
Image editor & 1 & 0 & 0 \\
Avatars & $44 \%$ & $11 \%$ & $35 \%$ \\
Web presentations & 0 & 0 & 0 \\
\hline
\end{tabular}

These percentages are based on the itineraries developed and class observations. The image edition tool requires the creation of an account to be able to use it, and at that time, account creation was not allowed. This tool was not used but visited. Certainly, the most visited and used resource was Avatars because it does not require registration and it is very attractive. It is important to highlight that the control group (without an itinerary) was not able to end any product due to the multiple extracurricular activities, to the public order issues that preserved the normal development of school activities and total dependency on teacher guidance. These difficulties were overcome thanks to the learning itineraries through which the students' autonomous work was evidenced.

\subsubsection{Data Triangulation}

A matrix to triangulate the results was generated from the assessed aspects using different information collection instruments. Thus, information collected was sorted in function of:

a) Indicators determined in the design stage:

- Competence development

- Satisfaction level

— Resources and activities 
b) Conceptual references:

- Competence development

- Previous knowledge

— Autonomy and self-learning

c) ICT-supported learning environment components:

- Methodology

— Interpersonal relationships

- Teacher's role

— Resources and activities

- Time

- ICT support

This organisation is schematically presented in Table 5.

Table 5. Result Triangulation of the results

\begin{tabular}{|c|c|}
\hline Criteria & Results \\
\hline $\begin{array}{l}\text { Development of } \\
\text { competence }\end{array}$ & $\begin{array}{l}\text { The itineraries support the development of the } \\
\text { competences and allow to overcome problems of } \\
\text { presentness. - Its flexibility and design enable to } \\
\text { generate a significant learning. }\end{array}$ \\
\hline $\begin{array}{l}\text { Previous } \\
\text { knowledge }\end{array}$ & $\begin{array}{l}\text { If the students have previous knowledge about } \\
\text { conceptual maps, they can interact with greater ease } \\
\text { with the itinerary. }\end{array}$ \\
\hline $\begin{array}{l}\text { Autonomy and } \\
\text { self-learning }\end{array}$ & $\begin{array}{l}\text { Students advanced according to their own pace and } \\
\text { interests, creating a greater level of autonomy and } \\
\text { self-learning. Never the less this process was } \\
\text { affected by the lack of clarity on the guides and the } \\
\text { teachers intervention, }\end{array}$ \\
\hline Methodology & $\begin{array}{l}\text { The participants liked the methodology used, while } \\
\text { acknowledging the need to be prepared to assume } \\
\text { the corresponding roles. }\end{array}$ \\
\hline $\begin{array}{l}\text { Interpersonal } \\
\text { relationships }\end{array}$ & $\begin{array}{l}\text { It generates peer support, which is further more } \\
\text { enhanced, if collaborative activities or some type of } \\
\text { interaction among the students, is designed. }\end{array}$ \\
\hline Teacher's role & $\begin{array}{l}\text { It was difficult for the teacher to assume the role of } \\
\text { a guide and even more on the experimental group } \\
\text { no. 2, where his support was virtual. Generally the } \\
\text { teachers are not prepared to have total control. }\end{array}$ \\
\hline Resources & $\begin{array}{l}\text { The itinerary had failures in terms of the associated } \\
\text { resources; some were not as clear as to generate } \\
\text { student's autonomous activity, reason why they had } \\
\text { to seek help. The guides must be very clear as well } \\
\text { as contextualized. }\end{array}$ \\
\hline Activities & $\begin{array}{l}\text { The activities programmed in the itinerary were } \\
\text { adequate for the development of competence, but } \\
\text { still students would have liked more interactive and } \\
\text { playful activities, dosed according to the time } \\
\text { available. The experts highlight the importance that } \\
\text { besides de description of the activity and support } \\
\text { resources, there must be a justification for the } \\
\text { relation they have with the competence develop- } \\
\text { ment. }\end{array}$ \\
\hline Time & $\begin{array}{l}\text { Time was very short and poorly administrated } \\
\text { during the activities execution. It is necessary to } \\
\text { include within the itinerary some type of control or } \\
\text { self-control tool in order to track progress. }\end{array}$ \\
\hline $\begin{array}{l}\text { Information and } \\
\text { communication } \\
\text { technology sup- } \\
\text { port }\end{array}$ & $\begin{array}{l}\text { Working with this methodology under the b- } \\
\text { learning modality provided better results. During } \\
\text { the development of the itinerary the students rely } \\
\text { on the information and communication technology, } \\
\text { in order to have interaction. }\end{array}$ \\
\hline Satisfaction level & $\begin{array}{l}\text { The satisfaction level shown on the surveys is } \\
\text { based on the motivation, flexibility, resources and } \\
\text { autonomy during the competence development. }\end{array}$ \\
\hline
\end{tabular}

\section{FINAL REFLECTIONS}

Obtained results allow us to conclude that flexible training itineraries based on conceptual maps support the development of competencies and allow overcoming in-class issues that may be evidenced in regular classrooms. In addition, its design and flexibility allow the generation of significant learning. However, it is important for students to keep in mind the competence they are developing.

The experience may be regarded as successful, because it can contribute to modelling the learning environment and implement instructional design leading to flexible training itineraries based on conceptual maps.

Another key aspect to be taken into consideration is teacher training throughout the expansion phase, focused on the role the teachers must assume for this type of experience and the guidance and conditions to create and implement their own itineraries.

To obtain better results in the application of flexible training itineraries based on conceptual maps, it is advisable to keep in mind that (Agudelo and Salinas, 2013):

The objective of the itinerary must be clear for participants.

Better results are obtained if itineraries are used under the blearning modality.

Training sessions on conceptual maps and CmapTools must be available before starting the work with itineraries.

Learning objects must be very clear, simple, contextualised and useful to develop the competence issue.

Itinerary learning activities and objects must be varied and offer options on how to perform chosen ones; according to multiple intelligences, this may cause a greater level of motivation and, therefore, more significant learning.

Symbols or colors may be used to identify learning objects within the itinerary; for instance, one color for activities and another for tutorials.

The teacher must assume the role of guide and encourage the students' autonomy and the flexibility allowed by the itinerary; the teacher must be trained in this issue.

It is important to validate the itinerary before applying it.

Design a self-control mechanism to develop the itinerary to help control time devoted to the programmed activities.

Results obtained in this project endorse the continuation of flexible training itinerary experience development, based on conceptual maps, in other levels of education (preschool, basic elementary, basic high school, intermediate, college, teacher training, continuous education), as well as the implementation of other versions of the applied itinerary, improving it from the performed assessment and applying it to the same schooling it was designed for, or developing other types of competencies in different educational contexts that may be expanded and characterise the focus of the model.

\section{REFERENCES}

Agudelo, O. L, \& Salinas, J. (2013). Diseños curriculares flexibles basados en mapas conceptuales para apoyar procesos de formación. In XVI Congreso Internacional EDUTEC 2013. doi:10.13140/RG.2.11578.7045

Ausubel, D. P., Novak, J. S., \& Hanesian, H. (1978). Educational psychology: A cognitive view. New York: Holt, Rinehart \& Winston. 
Berger, C., \& Kam, R. (1996). Definitions of Instructional Design. Adapted from "Training and Instructional Design". Applied Research Laboratory, Penn State. University. Retrieved from: http://www.umich.edu/ ed626/define.html

Broderick, C. L. (2001). Instructional Systems Design: What it's all about. Training Journal, 25.

Cañas, A. J., \& Novak, J. (2010). Itineraries: Capturing instructors experience using concept maps as learning object organizers. In J. Sanchez, A. Cañas, \& J. Novak (Eds.), Concept Maps: Making Learning Meaningful. Proceedings of the 4th Concept Mapping Conference CMC. Viña del Mar, Chile: Universidad de Chile.

Cañas, A. J., Novak, J. D., \& Reiska, P. (2015). How good is my concept map? Am I a good Cmapper? Knowledge Management \& E-Learning, 7(1), 6-19.

Cañas, A. J., Kenneth, M. F., Coffey, T. R., Roger, D. S., Hill, G., \& Niranjan, M. B. (2000). Herramientas Para Construir y Compartir Modelos de Conocimiento Basados en Mapas Conceptuales. Educational Informatics Magazine, 13(2), 145-158. Retrieved from: http://lidie.uniandes.edu.co/revista

Coffey, J. W., \& Cañas, A. J. (2003). LEO: A Learning Environment Organizer to Support Computer-Mediated Instruction. Journal for Educational Technology, 31(3), 275-290. doi:10.2190/6m2x-h2ra-19fk-9aw7

Coll, C. (2005). Psicología de la Educación y prácticas educativas mediadas por las tecnologías de la información y la comunicación: Una mirada constructivista. Sinéctica, 25, Sección Separata,1-24.

Collis, B., \& Moneen, J. (2001). Flexible Learning in a digital world. London: Kogan Page.

De Benito, B., Cañas, A., Darder, A., \& Salinas, J. (2010). Construcción y validación de un itinerario de aprendizaje sobre diseño y producción de materiales didácticos multimedia. In J. Sanchez, A. Cañas, \& J. Novak (Eds.), Concept Maps: Making Learning Meaningful. Proceedings of the 4th Concept Mapping Conference CMC (pp. 62-66). Viña del Mar, Chile: Universidad de Chile.

De Benito, B., Darder, A., \& Salinas, J. (2012). Los itinerarios de aprendizaje mediante mapas conceptuales como recurso para la representación del conocimento. Edutec-e. Revista Electrónica de Tecnología Educativa, 39. Retrieved from: http://www.edutec.es/revista/index.php/edutece/article/view/372

Kinchin, I. M. (2000). Using Concept Maps to reveal understanding. A two-tier analysis. School Science Review, 81, 41-46.

Lozano, A, \& Burgos, V. (2007). Tecnología educativa: en un modelo de educación a distancia centrado en la persona. Distrito Federal, Mexico: Limusa.

McKenney, S., Reeves T. C. (2012). Conducting Educational Design Research. Routledge, New York.

Novak, J. D., \& Gowin, D. (1984). Learning How to Learn. New York: Cambridge University Press. doi:10.1017/CBO9781139173469

Novak, J. D., \& Cañas, A. J. (2006). La teoría subyacente a los mapas conceptuales y a Cómo construirlos (IHMC CmapTools Report 2006-01): Retrieved from Institute for Human and Machine Cognition (IHMC) website: http://cmap.ihmc.us/docs/theory-of-concept-maps-spanish

Novak, J. D., \& Gowin, D. (1988). Aprendiendo a aprender. Barcelona: Ediciones Martínez Roca.

Ospina, D. P. (2008) ¿Qué es un ambiente virtual de aprendizaje?. Programa Integración de Tecnologías a la Docencia. Medellín, Colombia: Universidad de Antioquia. Retrieved from:

http://aprendeenlinea.udea.edu.co/banco/html/ambiente_virtual_de_aprendizaje

Reeves, T. C. (2006). Design research from the technology perspective. In J. Van den Akker, K. Gravemeijer, S. McKenney, \& N. Nieveen (Eds.), Educational design research (pp. 86-109). London: Routledge.

Salinas, J. (1999). Enseñanza flexible, aprendizaje abierto. Las redes como herramientas para la formación. Edutec-e. Revista electrónica de tecnología educativa, 10. Retrieved from: http://www.uib.es/depart/gte/revelec10.html

Salinas, J. (2004). Hacia un modelo de educación flexible: Elementos y reflexiones. In F. Martínez, \& M. P. Prendes (Eds.), Nuevas Tecnologías y Educación (pp. 145 -170). Madrid: Pearson/Prentice Hall.

Tait, A. (1999). The convergence of distance and conventional education. Some implications for policy. In A. Tait, \& R. MILLS (Eds.), The Convergence of Distance and Conventional Education. Pattenrs of flexibility for the individual learner (pp. 141-149). New York: Routledge. doi:10.4324/9780203260234

\section{ACKNOWLEDGMENT}

Funded by: Ministry of Science and Innovation, Spain.

Funder Identifier: http://dx.doi.org/10.13039/501100004837

Award: EDU2011-25499

Project: Methodological strategies for the integration of institutional, social and personal virtual learning environments 